\title{
MANAGEMENT STRATEGIES, YIELD AND POPULATION DEVELOPMENT OF THE NOBLE CRAYFISH ASTACUS ASTACUS IN LAKE STEINSFJORDEN.
}

\author{
J. SKURDAL (1)*, E. GARNÅS (2), T. TAUGBøL (1)
}

(1) Lillehammer University College, N-2626 LILLEHAMMER, Norway.

(2) Buskerud County Environmental Administration, P. O. Box 1604, 3007 DRAMMEN, Norway.

(3) Norwegian Institute of Nature Research, Fakkelgården, N-2624 LILLEHAMMER, Norway.

* Corresponding author / auteur pour correspondance.

\section{ABSTRACT}

Lake Steinsfjorden is the most important noble crayfish locality in Norway. The crayfish population has been monitored annually since 1979 including data on total trapping effort, yield and population composition before and after the catching season.

The harvest has ranged from 0.7-4.7 kg.ha ${ }^{-1}$. The catch per trap night decreased prior to 1991 and the yield was reduced by some 50\% over the years 1987-1992 as compared to 1979-1986. This was due to removal of small crayfish, high exploitation and the establishment of dense stands of Canadian pondweed (Elodea canadensis).

Baited traps catch a large fraction of crayfish $<95 \mathrm{~mm}$ total length minimum size. These should according to the regulations immediately be released into the lake. However, it is apparent from the size composition that release of these small crayfish was rather incomplete. In 1983, trap mesh size was increased from $17.5 \mathrm{~mm}$ to $21 \mathrm{~mm}$ to reduce the fraction of undersized crayfish in the trap catches, yet no effects of this increased mesh size on crayfish size distribution were observed. The legal season has been reduced three times during the study period. In 1983, the closing date was changed from 31 December to 15 September. In 1989 the legal season was further reduced to two weeks and finally in 1995 to 10 days. This reduced total trap effort by $45 \%$. The shorter season allow many crayfish to moult twice instead of once between seasons and the fraction of large crayfish has thus increased and so has the catch per trap night. Canadian pondweed has established dense annual stands and thus has made large parts of the shallow areas unsuitable for crayfish, causing an overall decrease in crayfish population size and production. 


\title{
STRATÉGIES DE GESTION, D'EXPLOITATION ET DE DÉVELOPPEMENT DES POPULATIONS DE L'ÉCREVISSE À PATTES ROUGES ASTACUS ASTACUS DANS LE LAC STEINSFJORDEN.
}

\begin{abstract}
RÉSUMÉ
Le lac Steinsfjorden représente le plus important stock d'écrevisses à pattes rouges de la Norvège. Le peuplement astacicole a été suivi chaque année depuis 1979 en enregistrant l'effort total de capture, le niveau d'exploitation et la composition de la population avant et après la saison de pêche.
\end{abstract}

La récolte est de 0,7 à $4,7 \mathrm{~kg} \cdot \mathrm{ha}^{-1}$. L'intensité de capture par nuit décroît jusqu'en 1991 et la récolte se réduit d'environ 50 \% entre 1987 et 1992 comparativement à la période 1979-1986. Ceci est lié à la capture de petits individus, à une forte exploitation et au développement d'importants herbiers à Elodée (Elodea canadensis).

Les nasses appâtées capturent une forte population d'écrevisses $<95 \mathrm{~mm}$ de longueur, taille minimum requise. Celles-ci devraient être relâchées dans le lac en accord avec la réglementation. Cependant, il est visible à partir de la composition en classes de taille que les rejets de ces petites écrevisses sont plutôt incomplets. En 1983, la taille des mailles des filets a été augmentée de $17,5 \mathrm{~mm}$ à $21 \mathrm{~mm}$ pour réduire la part des écrevisses trop petites dans les captures, aujourd'hui aucun effet de cette réduction n'est visible au niveau de la structure de population. Au cours de la période d'étude, la saison de pêche a été réduite trois fois. En 1983, la date de fermeture est passée du 31 décembre au 15 septembre. En 1989, la période de pêche a été réduite à deux semaines et à 10 jours en 1995. Tout ceci réduit l'effort de pêche de $45 \%$. Cette saison de pêche écourtée conduit de nombreuses écrevisses à muer deux fois au lieu d'une seule entre deux périodes de pêche et la proportion de grosses écrevisses s'est alors accrue, de même que les captures par nuit de pêche. L'élodée du Canada développe chaque année des herbiers denses et ainsi de vastes surfaces peu profondes deviennent impropres aux écrevisses, occasionnant une réduction de la population et de la production.

\section{INTRODUCTION}

Noble crayfish (Astacus astacus) has for a long period been subjected to exploitation due to its reputation as a delicacy and the species fetch high prices in the market. In suitable localities the yield is high and combined with the high prices noble crayfish is regarded as the most valuable resource. However due to crayfish plague and human alteration of the habitat, both the numbers of populations and the yield has declined rapidly by more than $95 \%$ during a period of nearly 150 years (SKURDAL and TAUGBØL, 2001). Noble crayfish is recognised as vulnerable by the EU Habitat Directive and is a species that needs special management schemes. The species is also included in international (IUCN, 1996) and national (DN, 1999) red lists. This implies that the management of noble crayfish needs to consider carefully the balance between conservation and utilisation.

The legislation varies between countries and this variation partly reflects differences in crayfish catching traditions (WESTMAN, 1991; SKURDAL et al., 1999; SKURDAL and TAUGBØL, 2001). In the Nordic countries the minimum legal size as well as season have been discussed (WESTMAN, 1991; HUNER et al., 1991, 1992) resulting in a fishery without national season or size restrictions in both Finland and Sweden. However there are a number of local regulations. Most of the harvested crayfish populations in Europe are managed through a variety of direct and indirect regulations of which various minimum 
sizes and catching seasons are the most important (WESTMAN et al., 1990; SKURDAL and TAUGBØL, 1994a). The legal catching season for noble crayfish varies considerably, and may last from two weeks to several months and also differ between males and females (WESTMAN et al., 1990; SKURDAL and TAUGBØL, 1994a, 2001). Regulations for crayfish catching have been disputed lately and both the necessity of regulations and the types of regulations have been questioned (HUNER et al., 1991; MOMOT, 1991; WESTMAN, 1991; ERKAMO et al., 1992; MOMOT, 1992; SKURDAL and TAUGBØL, 1994a, b).

The authors started to monitor the noble crayfish population in Lake Steinsfjorden in 1979. Based on the monitoring programme we now have a time series of 23 years, which include data such as total trapping effort, yield and population composition. During the study period, the regulations have been changed four times. This allows us to evaluate the long-term effects of the harvest regime on the crayfish population. Despite the fact that crayfish have been exploited for centuries in Europe and the considerable commercial interest, little is known about optimal management of wild populations and published data gives conflicting results and recommendations regarding harvest strategies and the need for regulations (WESTMAN, 1991, 1992; FISKERIVERKET, 1993, 1998). Based on the long and continuous record of crayfish in Lake Steinsfjorden, we here discuss different management strategies for noble crayfish and aim to give some general recommendations for the future management of harvestable stocks of noble crayfish in Europe.

\section{LAKE STEINSFJORDEN AND THE CRAYFISH FISHERY}

Lake Steinsfjorden is located in south-eastern Norway and has an area of $13.9 \mathrm{~km}^{2}$, max. depth of $22.6 \mathrm{~m}$ and a mean depth of $10.2 \mathrm{~m}$ (Figure 1). The lake is mesotrophic (10-12 $\mu \mathrm{g}$ phosphorus. $\mathrm{I}^{-1}$ ), well buffered (10-15 $\mathrm{mg} \mathrm{Ca.}^{-1}, \mathrm{pH}=7.2-9.3$ ) and the stony bottom substrate provide good shelter for all size groups of crayfish in the littoral zone (SKURDAL et al., 1992, 1993; SKURDAL and TAUGBØL, 1994b). Noble crayfish were introduced in the 1850s (HUITFELDT-KAAS, 1918). Since the turn of the century the crayfish population has been intensively exploited (HUITFELDT-KAAS, 1914; LUND, 1944). Lake Steinsfjorden is the most important crayfish locality in Norway, and accounts for some $25 \%$ of total harvest in our country (TAUGBØL and ERIKSEN, 1991). In 1977, Canadian pondweed, Elodea canadensis, was for the first time observed in the lake. Over the following years, the pondweed established dense covers over large parts of the shallow areas. The crayfish were gradually excluded from areas covered by Elodea and fishermen also avoided these areas. Direct observations by test-fishing and diving confirmed the absence of crayfish in these formerly densely populated areas (HESSEN et al., in prep.). According to the authors observations the littoral zone was not negatively affected by pondweed prior to 1980 .

The crayfish are mainly caught in baited, single funnel entrance traps constructed by local fishermen. The fishery is not licensed, and has high recreational and economical importance. The most active fishermen used some 400-600 traps each until 1998 when 300 traps became the upper limit for individual fishermen. In addition many visit the lake to trap crayfish a night or two for recreation. Exploitation increased rapidly during the 1970s as local fishermen used more traps and as the lake became popular among fishermen from other areas. The number of fishermen in 1990 was estimated to 400-500 (TAUGBØL and ERIKSEN, 1991).

Legal sized noble crayfish moult once or twice annually. The first moult is in mid-late July and the second in late August or early September. The second moult involves most males and the maturing females. Mean length increment per moult is $7.8 \mathrm{~mm}$ for females and $9 \mathrm{~mm}$ for males (SKURDAL and QVENILD, 1986). Females mature in the size interval 71-95 mm TL (SKURDAL and TAUGBØL, 1994a, b). 


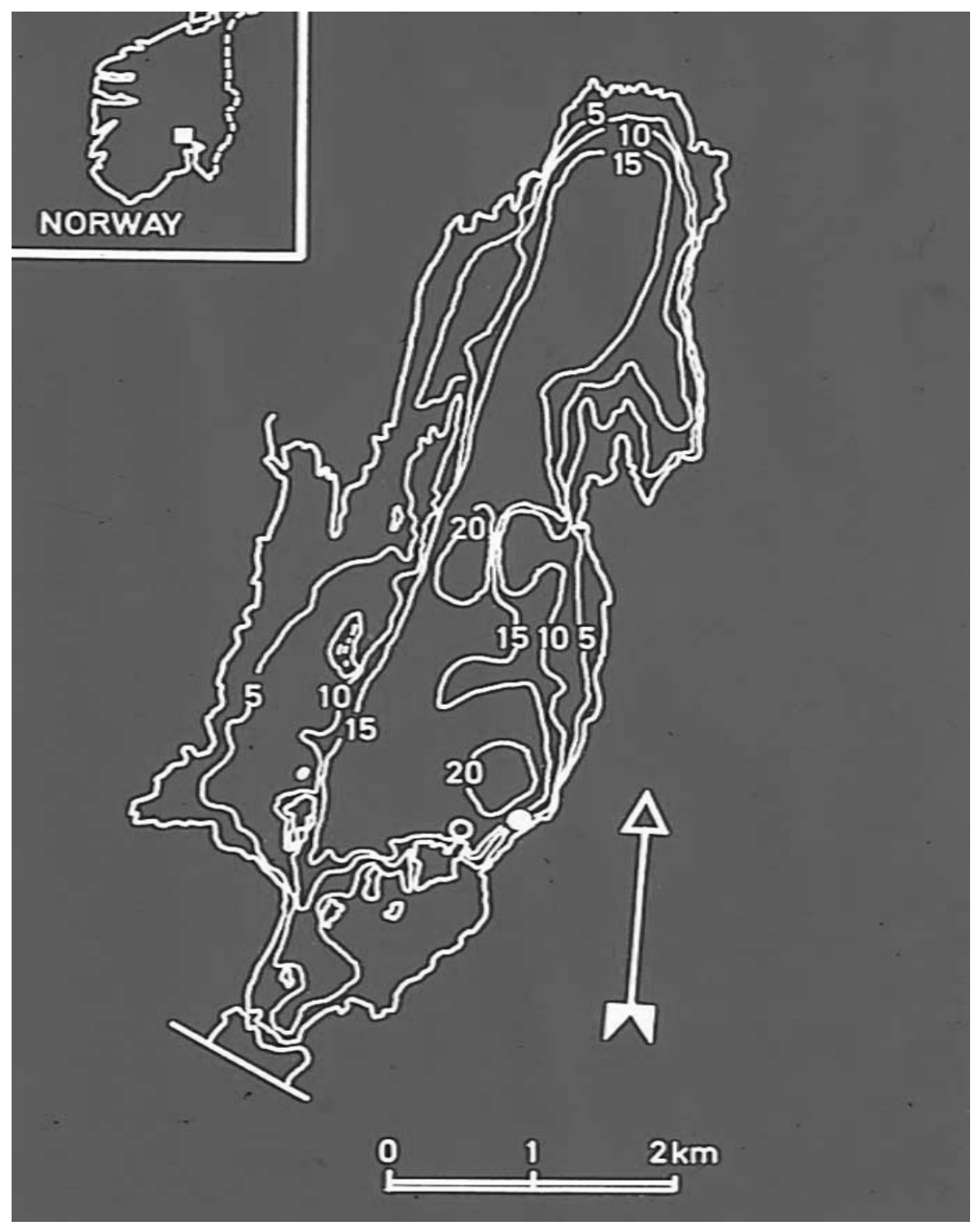

\section{Figure 1}

Map of Lake Steinsfjorden, SE Norway with depth contours.

\section{Figure 1}

Cartographie du lac Steinsfjorden (SE de la Norvège) avec les courbes bathymétriques en mètres.

The harvest regulations have been changed five times during the study period (Table I). The last change in legal season occurred in 1998, when the maximum number of traps per fisherman was set to 300 . In 1995, the legal season was reduced to 10 days with 16 August as the closing date. When the study started in 1979 the legal season lasted 146 days from 7 August to 31 December, the minimum legal size limit was $95 \mathrm{~mm}$ TL and the minimum trap mesh size was $17.5 \mathrm{~mm}$ (knot to knot). The new national regulations introduced in 1981 included the following changes; the legal season was reduced and 
lasted from 6 August at 18.00 to 15 September and minimum trap mesh size was increased to $21 \mathrm{~mm}$ (knot to knot) (in Lake Steinsfjorden this regulation was delayed to 1983). From 1989 the fishing season in Lake Steinsfjorden was limited to two weeks with 21 August as closing date. In 1997 the crayfish season was delayed two days due to poisonous algae and to test whether this influenced the crayfish meat.

\section{Table I}

Overview of the crayfish harvest legislation in Lake Steinsfjorden during the study period 1979-2000.

\section{Tableau I}

Evolution de la législation pour la capture des écrevisses du lac Steinsfjorden au cours de la période 1979-2000.

\begin{tabular}{|l|l|l|l|l|l|l|}
\hline \multirow{2}{*}{$\begin{array}{l}\text { Management } \\
\text { measures }\end{array}$} & \multicolumn{4}{|l|}{ Year } \\
\cline { 2 - 7 } & 1968 & 1981 & 1983 & 1989 & 1995 & 1998 \\
\hline Minimum size & $95 \mathrm{~mm}$ & & & & & \\
\hline Mesh size & $17.5 \mathrm{~mm}$ & & $21 \mathrm{~mm}$ & & & \\
\hline Season & 147 days & 39 days & & 14 days & 10 days & \\
\hline No. of traps & & & & & & Max. 300 \\
\hline
\end{tabular}

\section{MATERIAL AND METHODS}

Total trap effort is measured each season by two observers in a speedboat, based on 3-10 counts of traps during the catching season (SKURDAL et al., 1993) (Table II). Daily trap effort was determined assuming a constant daily reduction in trap effort between counts. Catch statistics (date, number of traps, number and total weight of legal sized crayfish) were collected from local fishermen representing a yearly trap effort of 2331 15512 trap nights or some $2.5-10 \%$ of the total effort. Based on an individual weight of $30 \mathrm{~g}$ at a length of $96 \mathrm{~mm} \mathrm{TL}$, there are approximately 33.5 legal sized crayfish. $\mathrm{kg}^{-1}$. The current first hand value of noble crayfish is some $250-350$ NOK. kg ${ }^{-1}$ (32.2245.11 EUR. $\mathrm{kg}^{-1}$ ). The traps of local fishermen reporting their catches were distributed in most of the lake and, therefore, accepted as representative estimates of total effort. Based on the catch statistics and the trap registrations we estimated total trap effort and yield (see SKURDAL et al., 1993). Due to the unusual cold spring and the delayed moulting in 1987 we were unable to produce reliable estimates for this single year.

Crayfish in the 1-10 m depth interval were sampled annually in the same area in preand post-season test fishing with baited individually set, one-funnel traps (SKURDAL et al., 1988, 1993). In total, 22951 crayfish were caught in baited traps in the pre-season test fishing (29 July-6 August) 1980-2000, and 9558 crayfish in the post-season test fishing (20 September-27 October) 1981-2000 (Table III). Trap effort ranged 44-150 in the pre- and 50-110 trap nights in the post-season test fishing, respectively. Catch per unit effort (CPUE) is expressed as individuals/trap night. Total length (TL), sex and stage of maturity of females were recorded. 
Table II

The yield of noble crayfish, Astacus astacus, in Lake Steinsfjorden, SE Norway in 1979-2000 (Registrations $=$ the number of times total number of traps were counted each season, Trap effort = estimated total trap effort during the season, CPUE = overall mean catch per unit effort of legal sized crayfish in baited traps and Yield = estimated catch of legal sized crayfish in number (N) and $\mathbf{k g}^{-h^{-1}}{ }^{-1}$.

\section{Tableau II}

Production d'écrevisses à pattes rouges Astacus astacus dans le lac Steinsfjorden (SE de la Norvège) de 1979 à 2000. (Registrations $=$ nombre de fois où les nasses ont été dénombrées au cours d'une saison, Trap effort = effort de pêche total au cours d'une saison, CPUE = capture par unité d'effort d'écrevisses à la taille légale dans des nasses appâtées, moyenne estimée dans l'ensemble de la saison, Yield = captures estimées d'écrevisses à la taille légale en nombre et kg.ha-1).

\begin{tabular}{|c|c|c|c|c|c|}
\hline Year & Registrations & Trap effort & CPUE & Yield (N) & ${\text { Yield }\left(\mathrm{kg} \cdot \mathrm{ha}^{-1}\right)}^{-1}$ \\
\hline 1979 & 8 & 146800 & 1.1 & 165300 & 3.6 \\
\hline 1980 & 6 & 168000 & 1.1 & 188100 & 4.1 \\
\hline 1981 & 10 & 160700 & 0.8 & 129700 & 2.8 \\
\hline 1982 & 9 & 134700 & 0.8 & 108800 & 2.4 \\
\hline 1983 & 9 & 137300 & 1.3 & 177100 & 3.9 \\
\hline 1984 & 8 & 142600 & 1.4 & 195800 & 4.3 \\
\hline 1985 & 7 & 164400 & 1.3 & 215500 & 4.7 \\
\hline 1986 & 7 & 170500 & 1.3 & 215100 & 4.7 \\
\hline 1987 & 7 & 173100 & 0.7 & 117900 & 2.6 \\
\hline 1988 & 5 & 180800 & 0.6 & 105100 & 2.4 \\
\hline 1989 & 3 & 99900 & 0.5 & 52000 & 1.1 \\
\hline 1990 & 3 & 105500 & 0.7 & 76700 & 1.7 \\
\hline 1991 & 3 & 100000 & 0.8 & 79300 & 1.4 \\
\hline 1992 & 4 & 110000 & 0.6 & 70500 & 1.3 \\
\hline 1993 & 4 & 136000 & 0.9 & 116300 & 2.7 \\
\hline 1994 & 4 & 119000 & 0.7 & 77500 & 1.8 \\
\hline 1995 & 3 & 98500 & 0.6 & 60300 & 1.4 \\
\hline 1996 & 3 & 106300 & 0.5 & 51700 & 1.2 \\
\hline 1997 & 3 & 46700 & 0.6 & 30100 & 0.7 \\
\hline 1998 & 3 & 70000 & 0.9 & 60300 & 1.4 \\
\hline 1999 & 3 & 67900 & 1.0 & 64600 & 1.5 \\
\hline 2000 & 3 & 65290 & 1.0 & 64600 & 1.5 \\
\hline
\end{tabular}

\section{RESULTS}

\section{Trap effort}

Crayfish trapping is very popular and on the opening night, we have registered from 8 200-24 400 traps, representing $6.0-17.9 \%$ of the total seasonal trap effort. The numbers of traps decrease rapidly, however, as the legal season has been reduced the development in daily trap effort has changed somewhat (Figure 2). Until 1989, the typical pattern was a rapid decline in trap number during the first week or two, then in late August or early September, trap effort increased slightly for a short period concurrently with the second moult, and thereafter trap effort again decreased. In connection with the second moult the 
catchability for the crayfish increased and also crayfish in the size interval 85-94 mm grew above the minimum size limit. However, when the season was reduced first to 14 days in 1989 and then to 10 days in 1995 the season closed before the second moult. The number of traps has therefore decreased throughout the catching season in the period after 1989. We must however point out that the pattern of decrease is influenced by our registration method. Trap number is registered 3-10 times during the season and is assumed to increase or decrease steadily between registrations, however the overall pattern is reflected with this method.

At least $50 \%$ of the total trap effort took place within the first 8-14 days prior to 1989 , when the season lasted until September 15. After the reduction in season in 1989, more than $50 \%$ of total trap effort took place within the first 4-6 days.

Table III

Results of experimental trapping of noble crayfish, $A$. astacus, in pre- and postseason test fishing with baited traps in Lake Steinsfjorden, SE Norway in 19802000 (Traps $=$ total number of trap nights, Number $=$ females and males combined, CPUE = total number of crayfish, all size groups, per trap night).

Tableau III

Résultats de captures expérimentales de l'écrevisse à pattes rouges, Astacus astacus à partir de tests avec des nasses appâtées en pré et post-saison dans le lac Steinsfjorden (SE de la Norvège) entre 1980 et 2000. (Traps = nombre total de nasses par nuit, Number $=$ femelles + mâles, CPUE $=$ nombre total d'écrevisses, toutes classes de tailles comprises, par nasse/nuit).

\begin{tabular}{|r|r|r|r|r|r|r|r|r|}
\hline \multirow{2}{*}{ Year } & \multicolumn{9}{|c|}{ Pre-season } & \multicolumn{4}{|c|}{ Post-season } \\
\cline { 2 - 10 } & Date & Traps & Number & \multicolumn{1}{c|}{ CPUE } & Date & Traps & Number & CPUE \\
\hline 1980 & $5-6.08$ & 100 & 2292 & 22.9 & & & & \\
\hline 1981 & $3-5.08$ & 150 & 3018 & 20.1 & 29.09 & 110 & 562 & 5.1 \\
\hline 1982 & $3-5.08$ & 126 & 2374 & 18.8 & 25.09 & 50 & 260 & 5.2 \\
\hline 1983 & $3-5.08$ & 150 & 1706 & 11.4 & 25.09 & 100 & 612 & 6.1 \\
\hline 1984 & 2.08 & 99 & 1392 & 14.1 & 27.10 & 50 & 260 & 5.2 \\
\hline 1985 & $1-3.08$ & 150 & 1465 & 9.8 & 21.09 & 50 & 279 & 5.6 \\
\hline 1986 & $30.07-6.08$ & 150 & 1349 & 9.0 & 25.09 & 50 & 284 & 5.7 \\
\hline 1987 & $3-7.08$ & 88 & 466 & 5.3 & 25.09 & 88 & 438 & 5.0 \\
\hline 1988 & 28.07 & 44 & 425 & 9.7 & 27.09 & 72 & 194 & 2.7 \\
\hline 1989 & 3.08 & 61 & 380 & 6.1 & 27.09 & 59 & 199 & 3.4 \\
\hline 1990 & 3.08 & 59 & 254 & 4.5 & 28.09 & 57 & 85 & 1.5 \\
\hline 1991 & 2.08 & 81 & 378 & 4.7 & 26.09 & 79 & 353 & 4.5 \\
\hline 1992 & 5.08 & 78 & 365 & 4.7 & 23.09 & 77 & 384 & 5.0 \\
\hline 1993 & 5.08 & 77 & 505 & 6.6 & 21.09 & 74 & 418 & 5.6 \\
\hline 1994 & 5.08 & 73 & 817 & 11.2 & 16.09 & 69 & 393 & 5.7 \\
\hline 1995 & 4.08 & 66 & 673 & 10.2 & 14.09 & 66 & 673 & 10.2 \\
\hline 1996 & 6.08 & 92 & 994 & 10.8 & 24.09 & 92 & 1003 & 10.9 \\
\hline 1997 & 4.08 & 88 & 854 & 9.7 & 17.09 & 88 & 854 & 9.7 \\
\hline 1998 & 5.08 & 82 & 1017 & 12.4 & 23.09 & 86 & 697 & 8.1 \\
\hline 1999 & 5.08 & 87 & 1088 & 12.5 & 1.10 & 88 & 827 & 9.4 \\
\hline 2000 & 5.08 & 85 & 1139 & 13.4 & 29.09 & 86 & 783 & 9.1 \\
\hline SUM & & & 22951 & & & & 9558 & \\
\hline
\end{tabular}


When the season was reduced from 39 to 14 days the decrease in number of traps was substantial (Figure 2). In the period 1989-2000 the trap effort decreased steadily during the legal season. Crayfish moulting in late August and growing larger than the legal size are not exploited as a result of the reduction of the season.

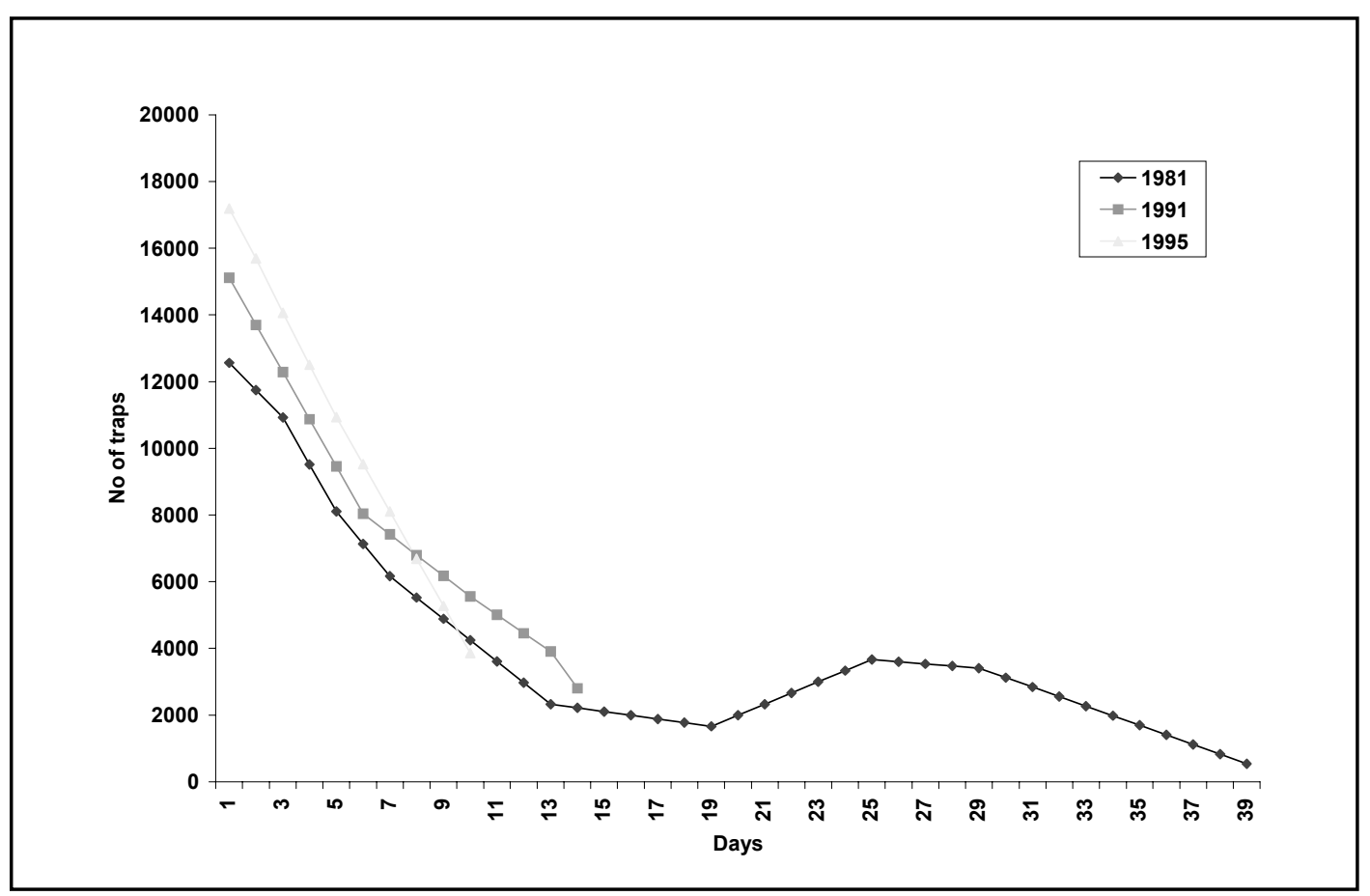

\section{Figure 2}

Daily trap effort in Lake Steinsfjorden, SE Norway, during the season in 1981, 1989 and 1995.

\section{Figure 2}

Effort de pêche sur le lac Steinsfjorden (SE de la Norvège), au cours des saisons 1981, 1989 et 1995.

Total trap effort has varied 4-fold between 46 700-180 800 trap nights in the period 1979-2000 (Table I, Figure 4). After the reduction in legal season in 1981, trap effort was slightly reduced but then it decreased again. The reduction in trap effort in 1981-1983 is probably influenced by the change in the legal mesh size which were adapted in 1981 and implemented in 1983. The legal mesh size increased from $17.5 \mathrm{~mm}$ to $21 \mathrm{~mm}$. The fishermen did not replace lost or destroyed traps, nor did they make or buy new traps in the period 1981-1983. The number of traps increased from 1983 and reached the highest level recorded in 1988, 180800 trap nights. This corresponds to 130 trap nights.ha $^{-1}$ for the whole lake area or 260 trap nights. ha ${ }^{-1}$ for the littoral zone. In 1989 the season was reduced to 14 days and the total trap effort was reduced by $42 \%$ compared to 1988 . However the number of traps started to increase again and by 1993 the total trap effort had increased by $40 \%$. The season was then reduced to 10 days and trap effort was reduced to less than 100000 trap nights. However one must also account for the invasion of pondweed. Stands of pondweed now cover some $50 \%$ of the shallow areas of the lake. Thus even if the total trap number has been reduced, the density of traps in areas without Elodea has not changed much. In some areas, the number of traps has even increased. 


\section{Yield}

The catch is highest during the first few days of the season due to a combination of high trap effort and catchability. During the first five days of the season CPUE usually is reduced by $50 \%$ and also the trap effort may be reduced by $50 \%$. Even in the period prior to 1989 more than $50 \%$ of the total catch were harvested within 5 days (Figure 3). However the shorter season implies that the total harvest is reduced. How much is not easy to interpret but maybe at least $25-30 \%$.

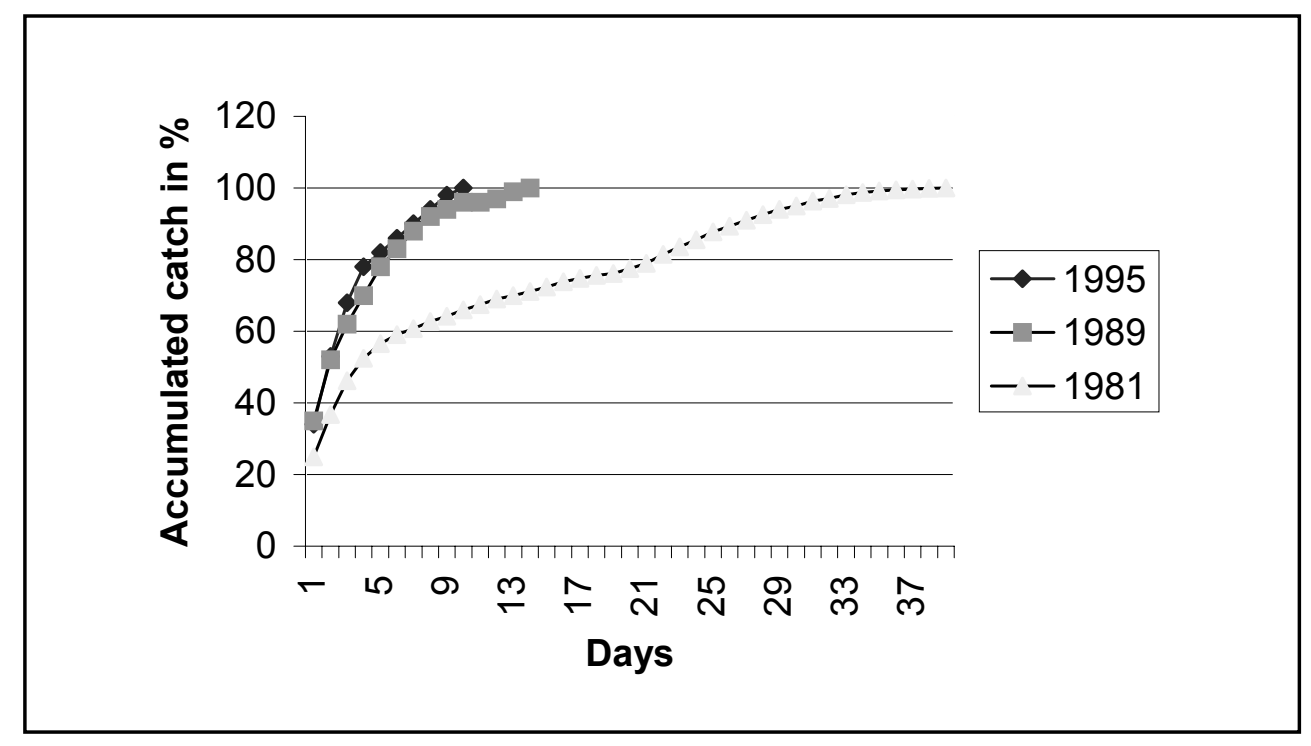

\section{Figure 3}

Accumulated catch (as \% of total) in Lake Steinsfjorden, SE Norway, during the season in 1981, 1989 and 1995.

\section{Figure 3}

Captures cumulées (en \% du total) dans le lac Steinsfjorden (SE de la Norvège) au cours des saisons 1981, 1989 et 1995.

The annual yield of noble crayfish in Lake Steinsfjorden has varied between $30100-$ 215500 crayfish in the period 1979-2000 (Table II, Figure 4). The total yield corresponds to $0.7-4.7 \mathrm{~kg} \cdot \mathrm{ha}^{-1}$ total lake area or 1.4-9.4 kg.ha ${ }^{-1}$ for the 0-10 metre depth interval. Yield decreased in the periods 1980-1982 and 1986-1989. Since 1994 the yield seems to have stabilised at some $1.4 \mathrm{~kg} \cdot \mathrm{ha}^{-1}$. The yield was only $0.7 \mathrm{~kg} \mathrm{ha}^{-1}$ in 1997, however this year the crayfish season was delayed 2 days and only lasted for 8 days.

\section{CPUE in pre- and post-season test fishing}

Pre-season test fishing CPUE has varied between 4.5-22.9 and post-season CPUE between 1.5-10.9 (Table III, Figure 5). Pre-season CPUE decreased steadily from 1980 until 1990. CPUE was low in the period 1990-1993, thereafter it increased until 1993 and then the CPUE has stabilized at a level of 10-13 crayfish per trap night over the last 7 years. Post-season test fishing CPUE yielded on average 5 individuals until 1988. The low post-season CPUE did apparently reflect a heavy exploitation and it seems that the crayfish population was reduced to the same level after each catching season. The variation in yield between years thus reflected variations in population size between years. 
In the period 1988-90 the post-season CPUE decreased. Corresponding with the implementation of the new legislation with a shorter season, post-season CPUE again increased and levelled off at approximately 10 crayfish per trap night during the last 6 years.

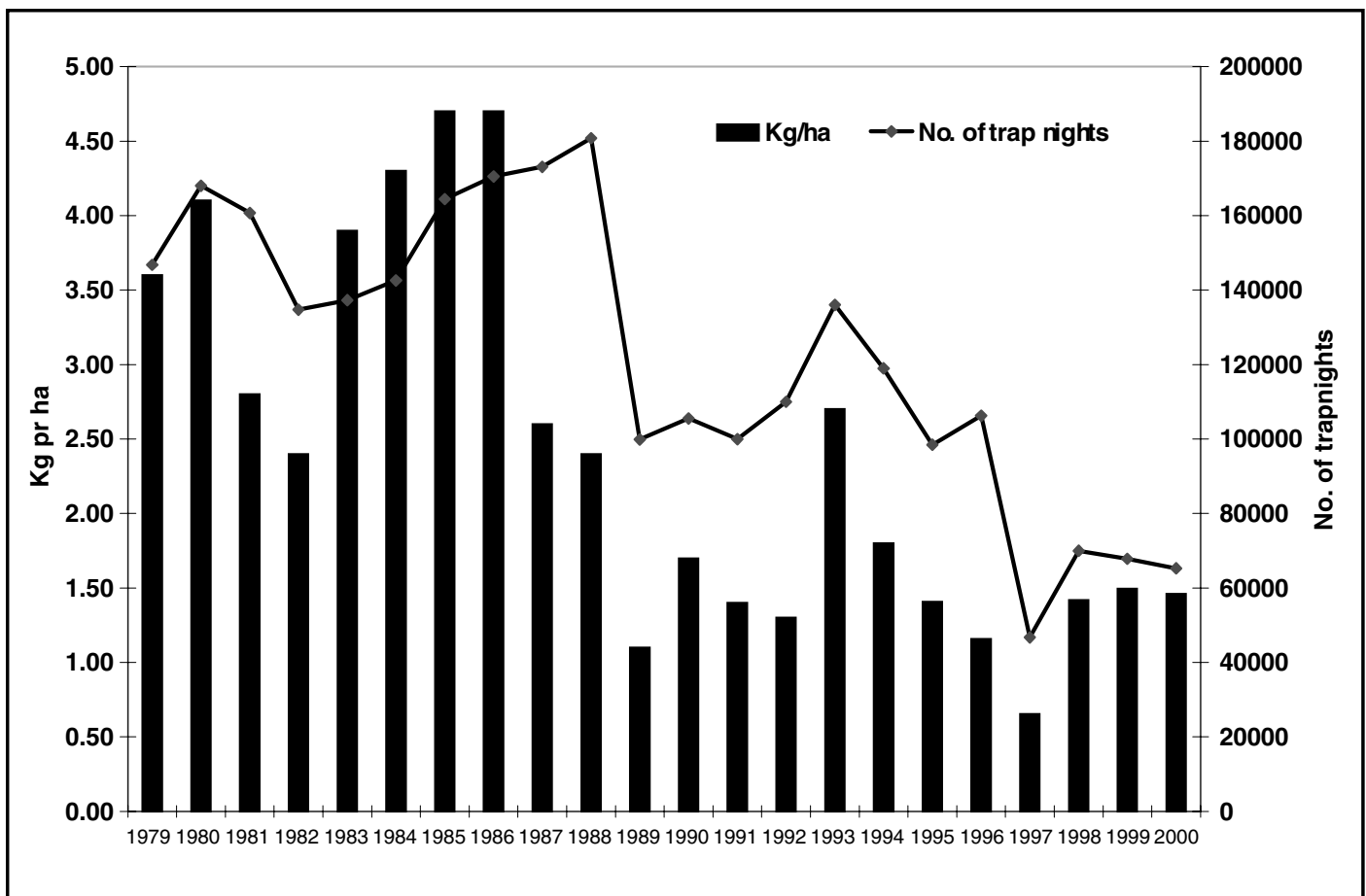

Figure 4

Annual trap effort and yield of noble crayfish, $A$. astacus, in Lake Steinsfjorden, SE Norway 1979-2000.

Figure 4

Effort de pêche et récoltes d'écrevisses à pattes rouges Astacus astacus de 1979 à 2000 dans le lac Steinsfjorden (SE de la Norvège).

\section{Population development}

The size composition in pre-and post season trap catches has varied and the fraction of legal sized crayfish in pre-season catches has ranged $16.2-72.6 \%$ and in postseason catches $5.0-43.5 \%$ (Figure 6). Due to a cold summer, and thus unusual late moulting in 1987, the fraction of legal sized crayfish was only $7.7 \%$ in pre-season catches. During the last few years the fraction of legal sized crayfish seems to have to stabilised at about $40 \%$ in pre-season catches and $20 \%$ in post-season catches. However year class strength and growth influence the fraction of legal sized crayfish as well as the fishery. The combination of rather high post-season CPUE and stable fraction of legal sized crayfish indicate that the recruitment is fairly good. Since the fraction of legal sized crayfish in postseason catches have stabilised at approximately $20 \%$ and the CPUE is high in the postseason test fishing it seems like the harvest is moderated by the current legislation and that population can sustain the current fishing pressure. 


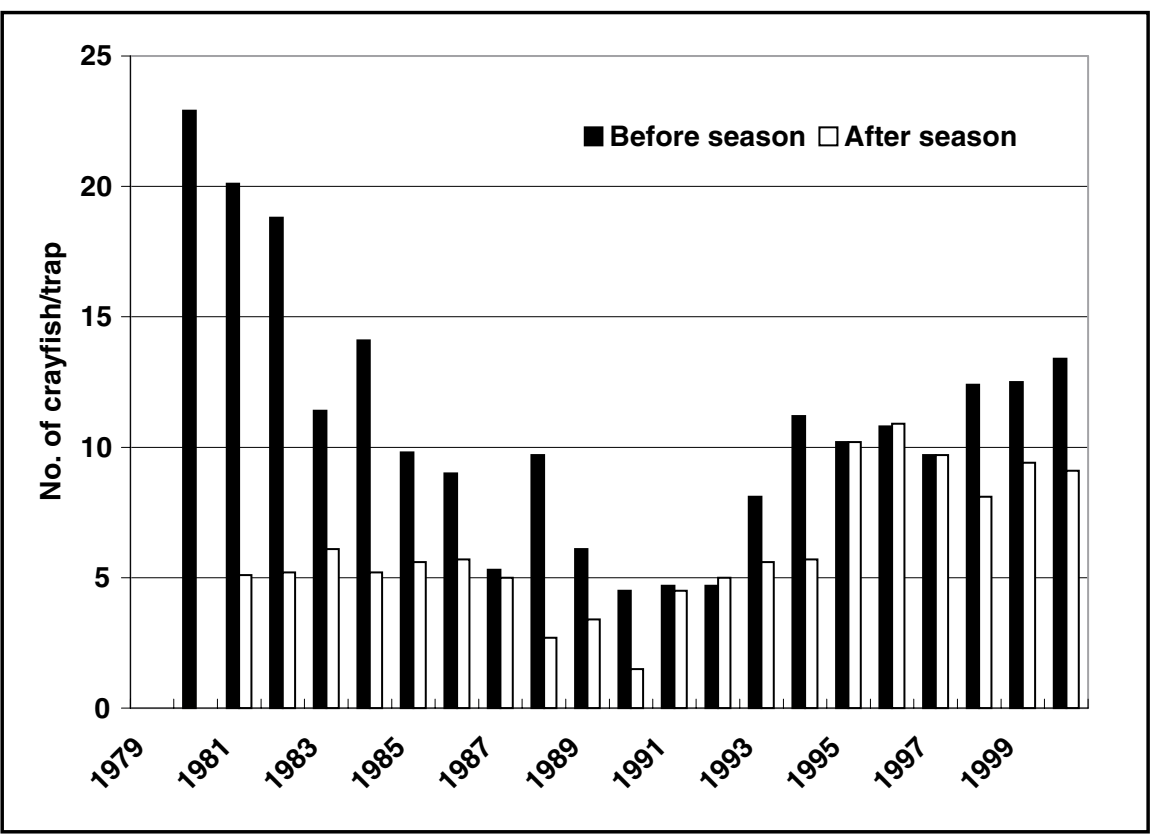

Figure 5

CPUE in pre- and post-season test fishing noble crayfish, $A$. astacus, in Lake Steinsfjorden, SE Norway in 1980-2000.

Figure 5

CPUE au cours des tests de capture de l'écrevisse à pattes rouges, Astacus astacus, en pré et post-saison de pêche dans le lac Steinsfjorden (SE de la Norvège) de 1980 à 2000.

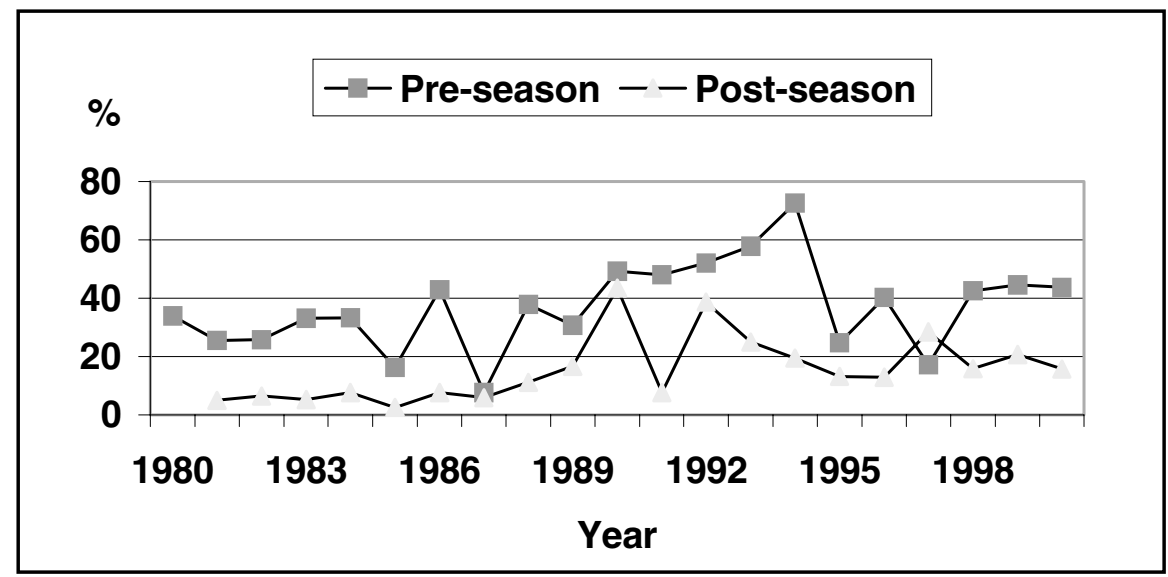

Figure 6

Fraction of legal sized crayfish in pre- post season trap catches noble crayfish, A. astacus, in Lake Steinsfjorden, SE Norway in 1980-2000.

Figure 6

Taux d'écrevisses à pattes rouges Astacus astacus à la taille légale dans les captures de pré et post-saison, dans le lac Steinsfjorden (SE de la Norvège) de 1980 à 2000. 


\section{DISCUSSION}

Fisheries have been regulated on the basis of politics, economics, social pressure, gear competition, prejudice, and whim, and sometimes for biological reasons. Emotions run high at hearings to discuss fishing regulations and crayfish fisheries are no exception. Noble crayfish regulations have been discussed by authorities, the public and scholars in recent year in Scandinavia (HUNER et al., 1991; MOMOT, 1991; WESTMAN, 1991; ERKAMO et al., 1992; MOMOT, 1992; SKURDAL and TAUGBØL, 1994a, b). The discussion includes a large variety of views and opinions, however the views are not strongly supported by data on effects of exploitations of noble crayfish or other Europeans species. The lack of scientific data on crayfish exploitation is surprising given the considerable interest for catching crayfish during several centuries.

Stocks of noble crayfish Astacus astacus are frequently heavily exploited in Scandinavia and thus it is necessary to develop a management tool that can control the exploitation. Exploitation of natural populations can be modified in two ways: (1) the total quantity harvested can be reduced or limited, or (2) the catch can be taken from a selected portion of the population (or selected portions of the population can be protected against capture) (EVERHART and YOUNGS, 1981). A limitation or reduction of the total catch is achieved by a limitation of the efficiency of the individual harvest units, limitation of harvest units or a limitation on the total quantity that can be captured (quota). Regulations designed to protect selected portions of the population may or may not result in overall reduction in catch. Such regulations include restrictions or modifications on the gear used to reduce catch of sizes or groups desired to protect; restriction of season, or restriction of size or sex. Often the term direct and indirect regulations are also used to describe various harvest regulations. In a crayfish fishery direct regulations include restrictions on number of crayfish per fisherman, day or license, and this type of regulation is well known among anglers (bag limits) and various types of commercial fisheries (quotas). Other direct regulations are size and sex restrictions. Frequently used indirect regulation methods include catch season, legal catching methods or equipment, mesh size and effort restrictions (number of traps and number of fishermen). Catching crayfish differs from most harvesting of natural species since all crayfish are caught alive and the catch may be sorted according to size or sex and even maturity if necessary. Mortality of crayfish released after being caught is probably very low if properly handled. Complex regulations including protection of selected portions of the populations are possible. However control and enforcement is a general problem in these types of regulations. Thus the favourable management scheme has to fulfil a number of requirements such as being easy to understand and accept among the various user groups, easy to control, give necessary protection to the stock as well as allowing optimal harvest. Any management scheme for crayfish therefore has to consider both biological and social issues in order to be successful (Figure 7).

The challenge for the authorities regarding the regulations in the Lake Steinsfjorden crayfish fishery has been to develop a management system, which does not imply restrictions on the number of fishermen or depends on resource-demanding control. The fishery in Lake Steinsfjorden is very special, since the Court, back in 1758 established access to the fishery for every Norwegian. The regulation of the fishery is thus the sole responsibility of the federal authorities, not including the landowners around the lake, which is the "normal" situation in Norwegian watercourses. The federal authorities have specific requirements for the regulations in the lake. The regulations were discussed in local hearings and it was important that the regulations were understood and accepted among local fishermen. The last change occurred in 1995, when the legal season was reduced to 10 days with 16 August as the closing date. When the study started in 1979 the legal season lasted 146 days from 7 August to 31 December, the minimum legal size limit was $95 \mathrm{~mm}$ TL and the minimum trap mesh size was $17.5 \mathrm{~mm}$ (knot to knot). The new national regulations introduced in 1981 included the following changes: the legal season was reduced and lasted from 6 August at 18.00 to 15 September, and minimum trap mesh size 
was increased to $21 \mathrm{~mm}$ (knot to knot) (in Lake Steinsfjorden this regulation was delayed to 1983). From 1989 the fishing season in Lake Steinsfjorden was limited to two weeks with 21 August as closing date. Thus, the schemes of regulations, which have evolved in Lake Steinsfjorden during the study period, include a combination of a minimum size of $95 \mathrm{~mm}$ total length and a short season. In addition the legal mesh size has increased from $17.5 \mathrm{~mm}$ to $21 \mathrm{~mm}$. The minimum size is a national regulation, which has been in operation for decades whereas the season is adapted specifically for the fishery in Lake Steinsfjorden during the study period.

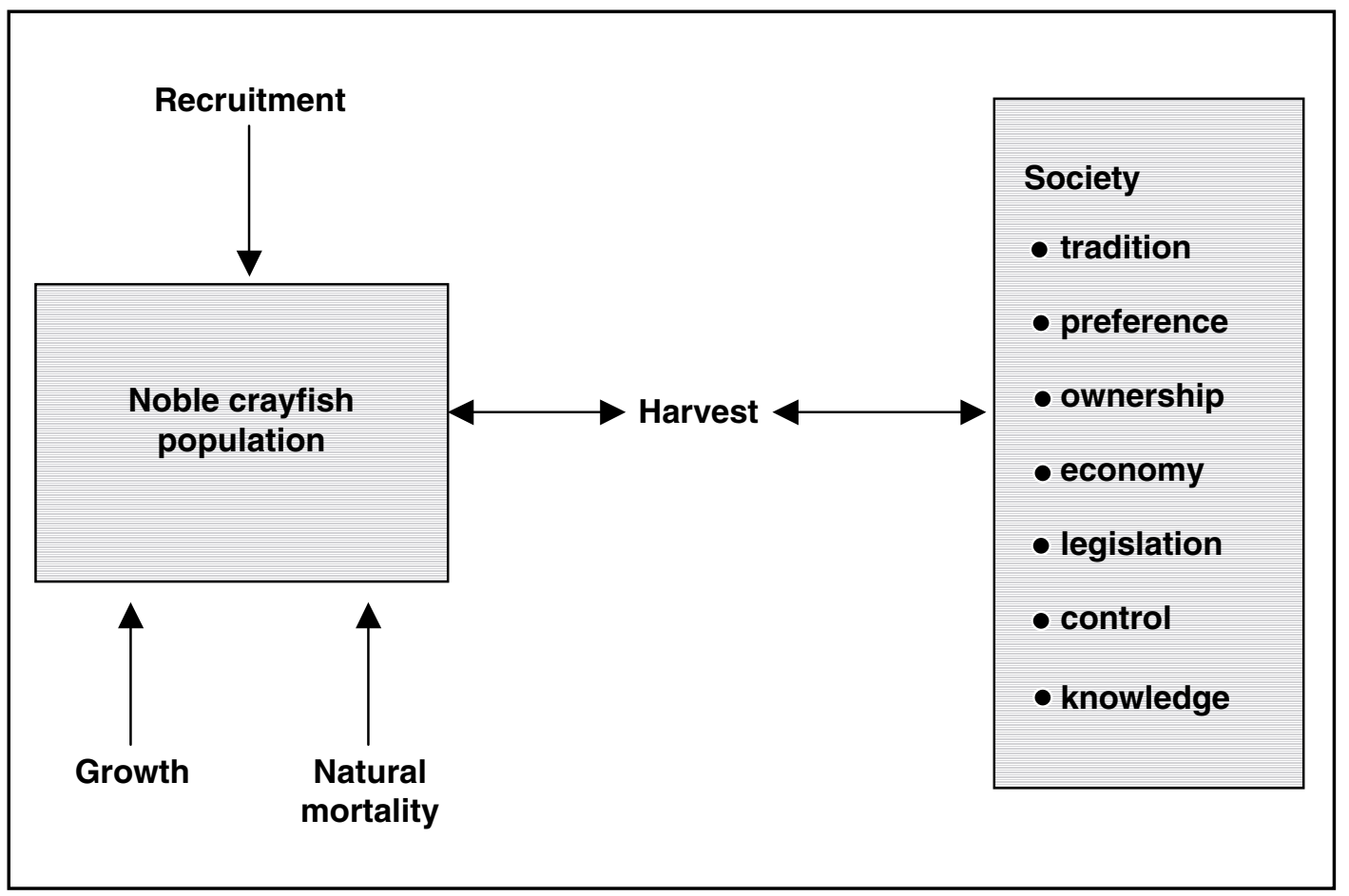

\section{Figure 7}

The management of noble crayfish has to consider both biological issues such as recruitment, growth and mortality, and social issues such as tradition for crayfish catching, preferences among the fishermen, ownership, economy, legislation, control and knowledge.

\section{Figure 7}

La gestion de l'écrevisse à pattes rouges doit prendre en compte les aspects biologiques tels que le recrutement, la croissance et les mortalités, mais aussi les aspects sociaux tels que la tradition de la pêche à l'écrevisse, les préférences des pêcheurs, le droit de propriété, l'économie, la législation, le contrôle et l'information.

The regulation in Lake Steinsfjorden is a combination of direct and indirect regulation with seasonal and size restrictions as the main practices. Seasonal restriction is an indirect method aimed at reducing total level of exploitation through a limitation in total trap effort. Minimum size is a direct method and crayfish smaller than $95 \mathrm{~mm}$ total length have to be released immediately. Control is easy to perform for the season restriction, however when it comes to minimum size control it is rather difficult and laborious. 
The minimum size is set to ensure that females mature at least once before being caught. Size at maturity varies among localities (SKURDAL and TAUGBØL, 1994a, b) and minimum size should preferably be adapted to the specific locality. In Lake Steinsfjorden, mean size of females is in the catch range $83-89 \mathrm{~mm}$ TL whereas the mean size of mature females is $83-87 \mathrm{~mm}$ TL (SKURDAL and TAUGBØL, 1994a). If there were no size restrictions baited traps obviously represent a potential for recruitment overfishing (RICKER, 1975; MOMOT, 1991). The fishermen's trap catches include approximately $75 \%$ non-legal crayfish (SKURDAL et al., 1995). All fishermen unfortunately do not strictly follow the size restrictions. Catching of non-legal crayfish has been a major problem in Lake Steinsfjorden and it is not possible to control the size limit with the current resources. The experience is that even though many fishermen strictly follow the regulations the minimum size is violated by many, however it seems like this problem have been reduced in later years. Some consume non-legal sized crayfish themselves but the main problem has been small crayfish being transplanted to other areas were the fishermen have more exclusive access. Season restrictions were therefore also included to reduce the total exploitation of the crayfish stock. The regulations are thus a combination of direct and indirect regulations. The direct regulations, i.e. legal size, are very difficult to control whereas the indirect regulations, i.e. legal season, are easily controlled. Another benefit derived from the short season is that males moult twice between catching seasons, and females in the size interval 87-94 $\mathrm{mm}$ moult and become mature before being subjected to trapping. Mean length increment per moult for adult crayfish is $7.8 \mathrm{~mm}$ for females and $9 \mathrm{~mm}$ for males (SKURDAL and QVENILD, 1986). This means that males may grow $18 \mathrm{~mm}$ between seasons and this corresponds to a weight increase of approximately $35 \%$ for legal sized crayfish (SKURDAL et al., 1991).

The invasion of pondweed obviously has greatly impacted the distribution and population size of crayfish and the crayfish harvest and may obscure interpretations of the data. Possibly the reduction in yield from 4.4 to 2.4 tonnes may be explained by pondweed now forming dense stands in approximately $50 \%$ of the $0-10 \mathrm{~m}$ depth interval (RØRSLETT et al., 1986; SKURDAL and QVENILD, 1989). Areas with dense Elodea stands are apparently completely avoided and the crayfish production in these areas are substantially reduced.

Our data from the monitoring program reveal large annual variations in trap effort and yield in the fishery, and also in CPUE and size composition in pre- and post-season test fishing. The variations are obviously connected to the exploitation of the crayfish, and during the study period total trap effort has varied by a factor of approximately four.

To conclude, so far we have learned that a combination of the national minimum size of $95 \mathrm{~mm}$ TL and the short season have been successful in Lake Steinsfjorden. The short season is very easy to control. The management scheme protects berried females and allows females to spawn at least once before being caught. Males may moult twice between legal seasons. There is no need to limit number of fishermen or number of traps per fisherman more than the current limit of 300 traps per fisherman. The yield has increased somewhat after the introduction of new regulations with a short season and seems to have stabilised at approximately $1.4 \mathrm{~kg} \cdot$ ha $^{-1}$ corresponding to a total annual yield of $2000 \mathrm{~kg}$. Regulation of crayfish fishery is not only a question of optimal harvest in terms of numbers of crayfish, it is also a question of economic yield. Present regulations increased yield both in number and quality, i.e. size. The current management scheme has increased the fraction of large sized crayfish and also the mean size of these. The current harvest corresponds to a first hand value of some NOK 500 000-750 000. The story of Lake Steinsfjorden also illustrates the usefulness of an annual low budget monitoring system. Due to the data from the annual programme local fishermen have accepted the changes in legislation and we have been able to develop a management scheme that works well for both the fishermen and the crayfish. 


\section{ACKNOWLEDGEMENTS}

During the study period we have received valuable help from a number of people. We are grateful for help from Terje Steinsæther, Truls Kristensen, Kjell Sundøen, Dag Hessen and Tore Qvenild. The study has received financial support from the Directorate for Nature Management, the Norwegian Institute of Nature Research and the County Governor in Buskerud.

\section{REFERENCES}

ERKAMO E., KIRJAVAINEN J., TULONEN J., 1992. Catching as a management method for crayfish. Finn. Fish. Res., 14, 77-83.

EVERHART W.H., YOUNGS W.D., 1981. Principles of fishery science. Cornell University Press, London, $349 \mathrm{p}$.

DIREKTORATET FOR NATURFORVALTNING, 1999. Nasjonal rødliste for truete arter i Norge 1998. DN-rapport, 3, 1-161 (In Norwegian).

FISKERIVERKET, 1993. Möjligheter att öka flodkräftbestånd i svanska vatten. Inf Sötvattenslab Drottningholm 2, 66 p. (In Swedish).

FISKERIVERKET, 1998. Möjligheter att öka flodkräftbestånd i svenska vatten. Inf Sötvattenslab Drottningholm 2, 66 p. (In Swedish).

HUITFELDT-KAAS H., 1914. A law proposal for the crayfish fishery. Bergen: J. Griegs boktrykkeri (Reprint of Norsk Fiskeritidende 8 and 9), 16 p. (In Norwegian).

HUITFELDT-KAAS H., 1918. Distribution and immigration of freshwater fishes and crayfish. Centraltrykkeriet, Kristiania, 106 p. (In Norwegian).

HUNER J.V., HENTTONEN P., LINDQVIST O.V., 1991. Observations on noble crayfish, Astacus astacus Linneaeus (Decapoda, Astacidae), populations in central Finland management implications. J. Shellfish Res., 10, 187-193.

HUNER J.V., HOLDICH D.M., WESTMAN K., 1992. Crayfish management strategies and management methods in Europe: a summary. Finn. Fish. Res., 14, 157-159.

IUCN, 1996. 1996 IUCN Red List of Threatened Animals. IUCN, Gland, Switzerland.

LUND H.M.K., 1944. A study of the food of crayfish. Nytt Mag for Nat. Vitenskap., B4, 219-250.

MOMOT W.T., 1991. Potential for exploitation of freshwater crayfish in coolwater systems: Management guidelines and issues. Fisheries, 16, 14-21.

MOMOT W.T., 1992. Stocking and exploitation as management methods for European crayfish. Finn. Fish. Res., 14, 145-148.

RICKER W., 1975. Computation and interpretation of biological statistics of fish populations. Bull. Fish. Res. Bd. Canada, 191, 382 p.

RØRSLETT B., BERGE D., JOHANSEN S., 1986. Lake enrichment by submersed macrophytes: a Norwegian whole lake experience with Elodea canadensis. Aquat. Bot., 26, 325-340.

SKURDAL J., QVENILD T., 1986. Growth, maturity, and fecundity of Astacus astacus in Lake Steinsfjorden, S.E. Norway. Freshwater Crayfish, 6, 182-186.

SKURDAL J., QVENILD T., 1989. Astacus astacus in Lake Steinsfjorden after Canadian waterweed Elodea canadensis invasion. Freshwater Crayfish, 7, 47-52.

SKURDAL J., TAUGBØL T., 1994a. Do we need regulations for catching crayfish? Rev. Fish Biol. Fish., 4, 461-485.

SKURDAL J., TAUGBØL T., 1994b. Biology, culture and management of the noble crayfish Astacus astacus (L.). Dr. Phil. thesis, Univ. of Oslo, Norway, 300 p.

SKURDAL J., TAUGBØL T., 2001. Astacus. In : Biology of Freshwater Crayfish, Part 2 Crayfish of Commercial Importance, HOLDICH D.M. (ed.), 467-510, Blackwell Science, Oxford. 
SKURDAL J., FJELD E., HESSEN D.O., TAUGBØL T., DEHLI E., 1988. Depth distribution, habitat segregation and feeding of the crayfish Astacus astacus in Lake Steinsfjorden. Nord. J. Freshw. Res., 64, 113-119.

SKURDAL J., QVENILD T., TAUGBØL T., GARNÅS E., 1991. Crayfish studies in Lake Steinsfjorden, Buskerud County, 1979-1990. County Governor in Buskerud, Environmental Adminstration Rep. 7-1991, 38 p. (In Norwegian).

SKURDAL J., QVENILD T., TAUGBØL T., 1992. Mark-recapture experiments with noble crayfish, Astacus astacus L., in a Norwegian lake. Aquac. Fish. Mgmt., 23, 227-233.

SKURDAL J., QVENILD T., TAUGBØL T., GARNÅS E., 1993. Long term study of exploitation, yield and stock structure of noble crayfish Astacus astcus in Lake Steinsfjorden. Freshwater Crayfish, 9, 118-133.

SKURDAL J., QVENILD T., TAUGBØL T., 1995. Size and sex composition of the noble crayfish Astacus astacus in Lake Steinsfjorden, S.E. Norway: effect of exploitation. Freshwater Crayfish, 8, 249-256.

SKURDAL J., TAUGBØL T., TUUSTI J., BURBA A., STYRISHAVE B., WESTMAN K., SÖDERBÄCK B., EDSMAN L., 1999. Crayfish introductions in the Nordic and Baltic countries. Crustacean Issues, 11, 193-219.

TAUGBØL T., ERIKSEN H., 1991. Krepsefisket i Norge 1990. Fylkesmannen i Oppland, miljøvernavdelingen, Rap 12: 23 p. (In Norwegian).

WESTMAN K., 1991. The crayfish fishery in Finland - its past, present and future. Finn. Fish. Res., 12, 187-216.

WESTMAN K., 1992. Management of the noble crayfish Astacus astacus (L.) and the signal crayfish Pacifastacus leniusculus (Dana) in Finland. Finn. Fish. Res., 14, 19-51.

WESTMAN K., PURSIAINEN M., WESTMAN P., 1990. Status of crayfish stocks, fisheries, diseases and culture in Europe. Report of the FAO European Inland Fisheries Advisory Commission (EIFAC) Working Party on Crayfish. Finnish Game and Fisheries Research Institute Report no 3, 1990, Helsinki, Finland. 